\title{
Tin determination in fistulae seals from Conimbriga and Augusta Emerita
}

\author{
S.S. Gomes ${ }^{(1)}$, P. Valério ${ }^{(1)}$, L.C. Alves ${ }^{(1)}$, M.F. Araújo ${ }^{(1), *}$, A. Monge Soares ${ }^{(1)}$, V.H. Correia ${ }^{(2)}$ \\ (1) Centro de Ciências e Tecnologias Nucleares, Instituto Superior Técnico, Universidade de Lisboa, \\ Estrada Nacional 10, km 139.7, 2695-066 Bobadela LRS, Portugal \\ (2) Museu Monográfico e Ruínas de Conímbriga, Condeixa-a-Velha, 3150-220 Condeixa, Portugal \\ * Corresponding author. \\ E-mail address:faraujo@ctn.ist.utl.pt
}

\begin{abstract}
Most Roman hydraulic systems were made with lead plumbing manufactured by casting lead sheets which were sealed by joining the edges with a molten metal. Modern studies suggest that the Romans used distinct techniques for joining the lead pipes (fistulae aquariae), such as welding (with lead) and soldering (with a tin-lead alloy). Micro-EDXRF and micro-PIXE analysis were used for micro-chemical characterization of joining areas of 13 water lead pipes collected in Roman archaeological contexts from Conimbriga and Augusta Emerita. Results indicate that two lead pipes from Conimbriga were sealed with a solder alloy, having a Sn content close to the eutectic point (61.9 wt.\%). The remaining fistulae seals have relatively low contents of $\mathrm{Sn}$ and also of other elements such as $\mathrm{Sb}$ and $\mathrm{Cu}$. Micro-analyses carried out along the pipes and welding regions show the use of lead with some impurities on both areas, while the elemental mapping of tin-lead solders show the presence of the $\alpha$ (lead-rich) and $\beta$ (tin-rich) phases.
\end{abstract}

Keywords:

Roman lead pipe; Tin-lead solder; Micro-EDXRF; Micro-PIXE

\section{Introduction}

Residential buildings, public baths and aqueducts usually had hydraulic systems made of lead plumbing (fistulae aquariae). The Roman manufacture technique of these pipes consisted on the casting of rectangular lead sheets, which were bent around a cylindrical bar and hammered into the desired shape $[1,2]$. The longitudinal pipe seams were made by joining the edges of lead sheets, while the joints between two pipes was usually made by overlaying an end of the lead pipe on the beginning of the other lead pipe. The sealing of the seams consisted on a moulded "box" of a cast metal, which makes up a good quality seal that is sufficient to withstand a high water pressure [3]. Upon installation the joints between pipes were sealed on site with a similar process.

In the classical literature, Pliny, the Elder, mentions that fistulae aquariae were joined with a $\mathrm{Pb}-\mathrm{Sn}$ solder (tertiarium) composed by two parts of lead and one part of tin. However, early research on Roman lead pipes have found that the joining material could either be composed by lead or lead with $5 \mathrm{wt} . \% \mathrm{Sn}$ or even by a tin solder with $25 \mathrm{wt}$ \% Sn, although the first seems to 
be clearly more common, as mentioned by Gowland in Wyttenbach and Schubiger [4]. Seven of these weld materials analysed by Gowland were made of ordinary lead with low Sn content: 0.6 $\mathrm{wt} \%$ for one fistulae from Portugal and $\leq 0.3 \mathrm{wt} \%$ for six from Switzerland. On the other hand, comparing the Sn content of the weld material with that of the pipe material the same concentration was found, except in two cases, where it was significantly lower in pipe material. Later, on the study of 21 pipes from Roman sites mostly located in Central Europe, but also including lead pipes from Caldas de Monchique and Coimbra (Portugal), two lead pipes from Switzerland were identified as being enriched with tin ( $18 \mathrm{wt} . \%)$ [4]. The authors suggest that these results indicate mixing of lead ingots with scrap lead of high tin content (probably as a result of using a tin-rich solder on that scrap lead) at the moment of preparing the melt to cast the lead sheets. More recently, additional evidence was found on the use of a tin solder in a fistulae joint from an imperial residence of the 3rd century AD in Rome [5].

Regarding the western end of the Roman Empire, namely the Lusitania province, there are no modern analytical studies about the manufacture of lead plumbing. Moreover, despite of the apparently undifferentiated use of the welding and soldering techniques among the Romans, the practical reasons to select such distinct methods are still unknown. Furthermore it should be noted that using or not of a tin solder can have a chronological significance, if we consider that Pliny wrote in the first century AD and many of the analysed lead pipes will be one or two centuries more recent. The use of lead requires a higher melting temperature $\left(\mathrm{T} \sim 327^{\circ} \mathrm{C}\right)$, but the solidification is much faster and produces a homogeneous seal with the lead pipe itself. On the contrary, the plumber solder mentioned by Pliny has a lower liquidus temperature $\left(\mathrm{T}_{\text {liq }} \sim 252\right.$ ${ }^{\circ} \mathrm{C}$ ) and a wide plastic range $\left(\Delta \mathrm{T} \sim 69^{\circ} \mathrm{C}\right)$, thus allowing the plumbarius to mould the seal by hand during cooling with the protection of a thick pad of cloth [6]. However, tin was a less common and more expensive raw material in the Roman Empire [7], so some economic constrains might also have an important role in the selection of the joining technique. This can be particularly true concerning Augusta Emerita, the capital of the Lusitania province, which was located near to important lead-rich mineral deposits $[1,8]$.

The present work proposes to investigate the techniques used to seal the fistulae at Conimbriga and Augusta Emerita, two important Roman centres in the ancient Lusitania province (Figure 1). A set of 16 samples was analysed by micro energy dispersive X-ray fluorescence spectrometry (micro-EDXRF) and micro particle induced X-ray emission spectrometry (microPIXE) to determine the composition of seams and joints, and of the lead pipe itself. These nondestructive techniques are commonly used to study the composition of ancient alloys $[9,10,11$, 12]. The samples selected for this work can thus shed some light on the use of different alloys and solders by the Roman plumbing technology. 
FIGURE 1

\section{Experimental}

\subsection{Samples and archaeological contexts}

The set of Roman lead fistulae seals selected for study was deposited in the Museu Monográfico e Ruínas de Conímbriga (MMC), Condeixa, and in Consorcio Ciudad Monumental de Mérida (M) and National Museum of Roman Art (MM), Mérida. The collected samples comprise seams (longitudinal pipe junctions) and joints (connection between pipes). A portion of the pipe itself was included in the sample in several cases (Figure 2).

\section{FIGURE 2}

Conimbriga was an important town of western Lusitania, a site with pre-Roman origins, conquered in the 2nd century $\mathrm{BC}$ and subject to significant urbanistic, architectonic and, specially, hydraulic engineering changes from the Augustan period onwards: the construction of the first bath complex and aqueduct, c. $10 \mathrm{BC}$; the generalization of water distribution, c. $\mathrm{AD}$ 40-50; and the creation of a particular style of garden architecture, heavily dependent on water, c. AD 125-150, of which the so-called "House of water-jets" is a prime example [13]. All samples from Conimbriga analysed on this work belong to the structures of this "House of water jets" (Table 1).

Augusta Emerita was the capital of Lusitania province. It was founded by Emperor Augustus in 27 BC, being an important centre for lead consumption and trade. Probably there were local metallurgical activities connected with lead artefacts production [1]. The analysed samples from Augusta Emerita belong to not recorded archaeological contexts (Table 1) and, consequently, their precise chronology is unknown.

\section{TABLE 1}

\subsection{Micro-EDXRF}

The non-invasive character of the X-ray fluorescence spectrometry has made it particular suitable in the analysis of cultural materials. However, due to the low penetration path of the incident X-ray beam as well of the characteristic X-ray lines emitted by the sample constituents, the obtained results are highly influenced by the corrosion layer commonly present in artefacts which have remained buried for long periods. Therefore to be able to ascertain about the bulk metal composition, the preparation of samples for analysis involved the removal of the corroded 
superficial layer and the polishing of the area to be analysed [14]. Optical microscopy observations were used to confirm a cleaned metallic surface for analysis.

Elemental composition analyses were performed using an ArtTAX Pro micro-EDXRF spectrometer comprising: a low-power molybdenum anode X-ray tube; a polycapillary lense that generates a spot of $\sim 70 \mu \mathrm{m}$ in diameter of primary radiation at the sample; a CCD camera and three beam-crossing diodes that provide the control over the exact position on the sample to be analysed; and a silicon drift electro-thermally cooled detector with a resolution of $160 \mathrm{eV}$ at $\mathrm{Mn}-\mathrm{K} \alpha$ [15]. Samples were analysed using $40 \mathrm{kV}, 0.5 \mathrm{~mA}$ and $200 \mathrm{~s}$ of tube voltage, current intensity and live time, respectively. Each sample was analysed in several spots in order to have the average composition or the element content profile in significant examples. Quantification was made with the WinAxil software using the fundamental parameter method.

In the absence of a lead-tin reference standard, the accuracy of method was assessed with the analysis of several gold-silver standard alloys [16]. The analogy was based on the analogous matrix effects for quantitative determinations of tin and silver in lead and gold matrices, respectively: the $\mathrm{Sn}-\mathrm{L} \alpha$ mass absorption coefficient in lead $-1581 \mathrm{~g} / \mathrm{cm}^{2}$ is quite comparable to the value of Ag-L $\alpha$ mass absorption coefficient in gold $-1644 \mathrm{~g} / \mathrm{cm}^{2}$ [17]. Therefore, obtained results demonstrated that the relative uncertainty of the method should be lower than $10 \%$ (Table 2).

\section{TABLE 2}

\subsection{Statistical treatment of the data}

Multivariate analysis was made with STATISTICA (v.12) software package comprising the principal components and factor analysis to reduce the number of dimensions and investigate the variability of the determined elements [18]. Factor analysis was performed on the obtained dataset to compare the compositional patterns $(\mathrm{Pb}, \mathrm{Sn}, \mathrm{Sb}$ and $\mathrm{Cu})$ between analysed samples. Factor loadings representative of the relative weight of each chemical element and factor scores representing the value of each sample regarding the new variables (factors) were calculated to ascertain about the identification of common sources.

\subsection{Micro-PIXE}

Elemental mapping analyses were carried out by micro-PIXE with an Oxford Micro-beams type set-up, using a $2 \mathrm{MeV}$ proton beam generated by a $2.5 \mathrm{MV}$ Van de Graaf accelerator. The Xrays emitted by sample elements were collected by a $30 \mathrm{~mm}^{2}$ SDD detector placed at a backward angle of $45^{\circ}$ and with $150 \mathrm{eV}$ of resolution. Beam currents of $100 \mathrm{pA}$ were used for 
all spectra and the beam spatial resolution was kept at $3 \times 4 \mu \mathrm{m}^{2}$. The data acquisition and beam scan were controlled by the OMDAQ as described in [19].

\section{Results and discussion}

\subsection{Elemental composition}

The results of micro-EDXRF analysis of Roman lead fistulae seals from Conimbriga and Augusta Emerita are displayed in Table 3.

\section{TABLE 3}

Most of the seals are composed by $\mathrm{Pb}$ (above 97.0 wt.\%) and low amounts of $\mathrm{Sn}$ (up to 2.80 wt.\%), $\mathrm{Sb}$ (up to $2.35 \mathrm{wt} . \%$ ) and $\mathrm{Cu}$ (up to $0.36 \mathrm{wt} . \%$ ). It is worth noting the different composition of two of the fistulae seals, the seam MMC26 and the joint MMC50 from Conimbriga, which are composed of tin-lead alloys with two parts of $\mathrm{Sn}$ and one part of $\mathrm{Pb}$, approximately (68.7 and $64.1 \mathrm{wt} . \%$, respectively). No compositional differences were found between lead seams and joints from the other fistulae, which display variable amounts of impurities. Moreover, except for two samples from Augusta Emerita, composed of highly pure $\mathrm{Pb}$ (99.9 wt.\%), there were no other significant differences between lead seals of the capital of the Lusitania province and the Roman town of Conimbriga.

The elemental composition of the analysed pipes (MMC42, MMC44 and MMC47) was rather close to the associated seams (MMC43, MMC45 and MMC48, respectively). All of them present high $\mathrm{Pb}$ concentrations (96.8 - 98.4 wt.\% $\mathrm{Pb}$ ), although some specific differences between pairs were noticeable for the minor elements (Table 3). To better understand the sealing of these lead pipes from Conimbriga, several micro-analyses were carried out along a cross-section that includes the pipe MMC47 and the seam MMC48 (Fig. 3).

\section{FIGURE 3}

Analytical determinations along this profile show rather small variations on the Sn content along the pipe and seam areas, which corroborate the Sn concentration obtained for each area using the micro-EDXRF (Table 3). The results indicate that the raw material for pipes and seals would be often the same. The variable Sn impurities determined on those samples can be originated by the usage of lead obtained from different ores (it seems to be the case of samples MM11 and MM12 compared with sample MMC51) or by the recycling of old lead pipes or other lead artefacts when Sn content is higher than $1 \%$ [20]. In brief, all this suggests that the casting process of the lead sheets would often consist in a mixing of scrap lead rich in Sn with lead ingots [4]. 
Overall, the composition of most fistula seals from Conimbriga and Augusta Emerita indicates the use of lead metal to seal the pipes, resulting in a homogeneous junction between pipe and seal. However, it is interesting to note that, according to Pliny, the Elder: "pieces of black lead cannot be soldered without the intervention of white lead, (...), nor can white lead, on the other hand, be united without the aid of black lead". The same author also refers that tin was melted with lead to form a tertiarium with a lead-tin 2:1 proportion for joining the pipes. In fact, two tin-rich solders were found in Conimbriga, but with a different composition (64.1 and 68.7 wt.\% - one part of lead and two parts of tin, approximately) from the soft solder mentioned by Pliny to be commonly used by plumbers. The kind of solder identified in those two pipes seems to be applied mostly for fine work [21], being a hypereutectic alloy with a much lower solidus/liquidus temperature than the melting point of the lead pipe (i.e. $327^{\circ} \mathrm{C}$ for pure lead).

\subsection{Multivariate analysis}

Principal components and factor analysis applied to the composition of fistulae seals from Conimbriga and Augusta Emerita comprised four variables ( $\mathrm{Pb}, \mathrm{Sn}, \mathrm{Sb}$ and $\mathrm{Cu}$ contents) and 13 samples (fistulae seals) originating two factors that report about $91 \%$ of the total variance in the original data set (Table 4).

\section{TABLE 4}

Factor loadings show that factor 1 is mostly related with $\mathrm{Pb}$ (inversely) and $\mathrm{Sn}$ (directly), while the factor 2 can be directly associated with $\mathrm{Sb}$ and $\mathrm{Cu}$ (Table 4 and Fig. 4). This layout suggests that the $\mathrm{Sb}$ and $\mathrm{Cu}$ have a different origin than $\mathrm{Sn}$, thus probably not resulting from lead recycling but on different ores used. The plot of factor scores shows three well defined groups. Group 1 is composed by the $\mathrm{Sn}-\mathrm{Pb}$ solders from Conimbriga. Group 2 includes the majority of seams and joints displaying variable $\mathrm{Sn}, \mathrm{Sb}$ and $\mathrm{Cu}$ contents. The third group has only one sample (MMC51) having the higher amounts of $\mathrm{Sb}$ and $\mathrm{Cu}(2.35$ wt.\% and 0.36 wt.\%, respectively) and no Sn. This distinct composition suggests a different raw material, probably a lead ore with higher concentration of $\mathrm{Sb}$ and $\mathrm{Cu}$. However, it should be taken into account that the "House of water jets" suffered an extensive refurbishment during the Roman time which suggests the existence of lead mixtures from different raw material.

\section{FIGURE 4}

The elemental composition of samples from Conimbriga also suggests that regular use of lead scrap with Sn impurities on the casting of lead sheets was a common practice. The elemental composition of the analysed Roman fistulae seals also indicates the use of two joining methods 
namely soldering with $\mathrm{Sn}-\mathrm{Pb}$ alloys or welding with ordinary lead. The first was only identified in Conimbriga, while the second seems to be more common making use of whatever lead was available, either pure or recycled.

\subsection{Elemental mapping of seals}

The fistulae showing Sn-Pb solders (seam MMC26 and joint MMC50) and a seam with $\mathrm{Sn}$ impurities (MMC48) were further studied by micro-PIXE elemental mapping in order to investigate the homogeneity of those Roman seals (Fig. 5).

\section{FIGURE 5}

The edge of the pipe in sample MMC26 is clearly visible on the right side of the elemental maps, being obviously mostly composed of lead. Adjacent to this edge is the layer of $\mathrm{Sn}-\mathrm{Pb}$ solder (about $740 \mu \mathrm{m}$ thickness) showing lead-rich areas interposed with tin-rich areas. The two different phases in this hypereutectic solder therefore correspond to the $\alpha$ and $\beta$ phases, respectively. The copper shows a homogeneous distribution without significant differences between the pipe and solder. The joint MMC50 has a similar microstructure composed of leadrich and tin-rich areas (a spot analysis in one of the latter shows 98.5 wt.\% Sn). These tin-rich solders with composition close to the eutectic alloy and low melting point $\left(\sim 190^{\circ} \mathrm{C}\right)$ have a very short plastic range $\left(\Delta \mathrm{T} \sim 10^{\circ} \mathrm{C}\right)$, thus not been very appropriated for plumbing, since a high plastic range allows a better moulding during cooling, thus ensuring better sealing of the pipes. Moreover, such tin contents result on a more expensive solder than the tertiarium since tin was more expensive than lead [8]. The use of this tin rich solder can be related to chronological issues or its use was due to a practical reason: unavailability of the common solder (tertiarium). The lead seam MMC48 illustrates a quite distinct homogeneous distribution of $\mathrm{Sn}$ in comparison to $\mathrm{Sn}-\mathrm{Pb}$ solders (Fig. 5). Similarly, the cross section of the pipe MMC47 and seam MMC48 (Fig. 6) confirms a homogeneous sealing of the pipe with molten lead indicating a proper plumbing technology of those Roman workers.

\section{FIGURE 6}

\section{Conclusion}

The microchemical characterisation of Roman fistulae seals from Conimbriga allows the identification of two different joining techniques: welding and soldering with a tin-rich solder, being first the most widely used. Only two solders with 68.7 wt.\% and 64.1 wt.\% Sn contents were found, being these amounts very different from the proportion mentioned by Pliny, the Elder (first century AD) for tin solders in use by plumbers. The remaining fistulae seals have 
low Sn contents indicating that only lead was used for seal the junctions. Moreover, in Augusta Emerita only the welding technique was identified. All these results suggest that the use of lead metal was a common plumbing technique for sealing the junctions of fistulae aquariae among the Roman world in the Lusitania province, even because lead is a cheap metal and the molten lead produces a quite homogeneous seal with the lead pipe, i.e. a good quality seal that can withstand a high water pressure.

The present study also suggests that the recycling of lead for both pipes and seals was very common, although the use of very pure lead, probably not recycled, is also particularly attested in Augusta Emerita. Perhaps, this is a consequence of the large amount of lead available as a byproduct from the silver metallurgy (cupellation), which was strongly developed under Roman rule in the Southwestern Iberia.

Nevertheless, further research must be implemented in order to know if the use or not of tin solder in the sealing of fistulae aquariae has a chronological or regional significance. Analyses of samples from other origins and with a more precise chronology can shed light on these issues.

Finally, these microchemical techniques proved to be important and able to reach significant results on the study of cultural heritage, namely of archaeological artefacts that must be preserved in its total integrity.

\section{Acknowledgements}

Susana Sousa Gomes acknowledges the FCT grant SFRH/BD/88002/2012. C ${ }^{2}$ TN/IST authors gratefully acknowledge the FCT support through the UID/Multi/04349/2013 project. Authors are thankful to the Department of Conservation and Restoration (DCR/FCT/UNL) for the use of the micro-EDXRF spectrometer and Luis Hidalgo (Consorcio Ciudad Monumental de Mérida) and Josefina Melinda (National Museum of Roman Art, Mérida) to provide some artefacts.

\section{References}

[1] A.I. Cano Ortíz, J. Acero Pérez, Los usos del plomo en la ingeniería hidráulica romana. El caso de Augusta Emerita, Memoria 7 (2004) 381-396.

[2] V. Costa, F. Urban, Lead and its alloys: metallurgy, deterioration and conservation, Reviews in conservation 6 (2005) 48-62.

[3] R.F. Tylecote, A History of Metallurgy, second ed., The Institute of Materials, London, 1992. 
[4] A. Wyttenbach, P.A. Schubiger, Trace element content of roman lead by neutron activation analysis, Archaeometry 15(2) (1973) 199-207

[5] E. Paparazzo, Surface and interface analysis of a Roman lead pipe "fistula": microchemistry of the soldering at the join, as seen by scanning Auger microscopy and X-ray photoelectron spectroscopy, Appl. Surf. Sci. 74 (1994) 61-72.

[6] H. Maryon, Metal working in the Ancient World, Am. J. Archaeol. 532 (1949) 93-125.

[7] J. Riederer, The use of standardised copper alloys in Roman metal technology, in: A. Giumlia-Mair (Ed.), Atti del 15 Congresso Internazionale sui Bronzi Antichi: produzione e tecnologia, Grado-Alquileia 22-26 maggio 2001. Montagnac, Mergoil, 2002, pp. 284-291.

[8] J. Acero Pérez,A.I Cano Ortíz, El plomo y sus aplicaciones en una ciudad roman: Augusta Emerita, Sautuola XIII (2007) 543- 556.

[9] P. Valério, M.F. Araújo, R.J.C. Silva, Complementary use of X-ray methods to study ancient production remains and metals from Nothern Portugal, X-ray Spectrom. 43 (2014) 209-215, http://dx.doi.org/10.1002/xrs.2541.

[10] R. Fernades, B.J.H. van Os, H.D.J. Huisman, The use of Hand-Held XRF for investigating the composition and corrosion of Roman copper-alloyed artefacts, Herit. Sci. 1:30 (2013) 1-7, http://dx.doi.org/10.1186/2050-7445-1-30.

[11] F. Rizzo, G.P. Cirrone, G. Cuttone, A. Esposito, S. Garraffo, G. Pappalardo, L. Pappalardo, F.P. Romano, S. Russo, Non-destructive determination of silver content in Roman coins (nummi), dated to 30-311 A.D., by the combined use of PIXE-alpha, XRF and DPAA techniques, Microchem. J. 97 (2011) 286-290, http://dx.doi.org/10.1016/j.microc.2010.09.017.

[12] M.F. Araújo, T. Pinheiro, P. Valério, A. Barreiros, A. Simionovici, S. Bohic, A. Melo, Analysis of a Roman Centaurus from Canas de Senhorim (Portugal) - Comparative study using EDXRF and SXRF, J. Phys. IV France 104 (2003) 523-526,

http://dx.doi.org/10.1051/jp4:20030137

[13] M.P. Reis, V.H. Correia, Jardins de Conimbriga: arquitectura e gestão hidráulica, in J-P. Morel, J.T. Juan, J.C. Matamala (Eds), Proceedings of the 1st Conference on Crop Fields and Gardens Archaeology, Barcelona 1-3 June, Edipuglia, Bari, 2006, pp. 293-312.

[14] E. Figueiredo, P. Valério, M.F. Araújo, J.C. Senna-Martinez, Micro-XRF surface analyses of a bronze spear head: lead content in metal and corrosion layers, Nucl. Inst. Methods Phys. Res. A 580 (2007) 725-727, http://dx.doi.org/10.1016/j.nima.2007.05.135

[15] H. Bronk, S. Rohrs, A. Bjeoumikhov, N. Langhoff, J. Schmalz, R. Wedell, H.E. Gorny, A. Herold, U. Waldschlager, ArtTAX - a new mobile spectrometer for energy-dispersive micro Xray fluorescence spectrometry on art and archaeological objects, Fresenius J. Anal. Chem. 371 (2001) 307-316.

[16] M.F.D. Araújo, L.C. Alves, J.M.P. Cabral, Comparison of XRF and PIXE in the analysis of ancient gold coins, Nucl. Inst. Methods Phys. Res. B 75 (1993) 450-453. 
[17] R. Tertian, F. Claisse, Principles of quantitative X-ray fluorescence analysis, Heyden, London, 1982.

[18] D.L. Massart, B.G.M. Vandeginste, S.N. Deming, Y. Michotte, L. Kaufman, Chemometrics: A Textbook. Elsevier, Amsterdam, 1988.

[19] L.C. Alves, M.B.H. Breese, E. Alves, A. Paul, M.R. Silva, M.F. Silva, J.C. Soares, Micronscale analysis of $\mathrm{SiC} / \mathrm{SiCf}$ composites using the new Lisbon nuclear microprobe, Nucl. Inst. Methods Phys. Res. B 161 (2000) 334-338.

[20] Y. Kahanov, D. Ashkenazi, D. Cvikel, S. Klein, R. Navri, A. Stern, Archaeometallurgical analysis of metal remains from the Dor 2006 shipwreck: A clue to the understanding of the transition in ship construction, J. Archaeol. Sci.: Reports 2 (2015) 321-332, http://dx.doi.org/10.1016/j.jasrep.2015.02.013.

[21] J.A. Smythe, Notes on ancient and Roman tin and its alloys with lead, Trans. Newcom. Soc. 18 (1937) 255-266. 


\section{FIGURE CAPTIONS}

Fig. 1. Location of Conimbriga and Augusta Emerita in the Lusitania province.

Fig. 2. Examples of the fistulae seals from Conimbriga and Augusta Emerita: a) seam; b) joint between two pipes.

Fig. 3. Micro-EDXRF analysis of the cross section of sample composed by pipe MMC47 and seam MMC48 (top right area in figure).

Fig. 4. Plot of Factor 1 versus Factor 2 loadings $(\mathrm{Cu}, \mathrm{Sn}, \mathrm{Sb}$ and $\mathrm{Pb})$ and scores (13 fistulae seals samples).

Fig. 5. Micro-PIXE elemental distribution maps of cross-sections of samples MMC26 (seam), MMC48 (seam) and MMC50 (joint) (scan $1060 \times 1060 \mu \mathrm{m}^{2}$; colour range from blue to red, representing from low to high intensity).

Fig.6. Micro-PIXE elemental distribution maps of cross-section of samples MMC47 and MMC48 (pipe and seam, respectively) (scan $2640 \times 2640 \mu \mathrm{m}^{2}$; colour range from blue to red, representing from low to high intensity). 


\section{TABLE CAPTIONS}

\section{Table 1}

Identification of seams, joints and lead pipes from Conimbriga (MMC - Museu Monográfico e Ruínas de Conímbriga) and Augusta Emerita (M - Consorcio Ciudad Monumental de Mérida, and MM - Museo Nacional de Arte Romano de Mérida).

Table 2

Micro-EDXRF analyses of standards Au80Ag20 and Au90Ag10 (average \pm standard deviation).

\section{Table 3}

Results of micro-EDXRF analysis of the fistulae seals from Conimbriga and Augusta Emerita (n.d. - not detected; * pipes associated to seams)

\section{Table 4}

Factor loadings of principal components of $\mathrm{Pb}, \mathrm{Sn}, \mathrm{Sb}, \mathrm{Cu}$ contents on the fistulae seals from Conimbriga and Augusta Emerita (varimax normalized; bold: factor loadings with absolute value higher than 0.7). 


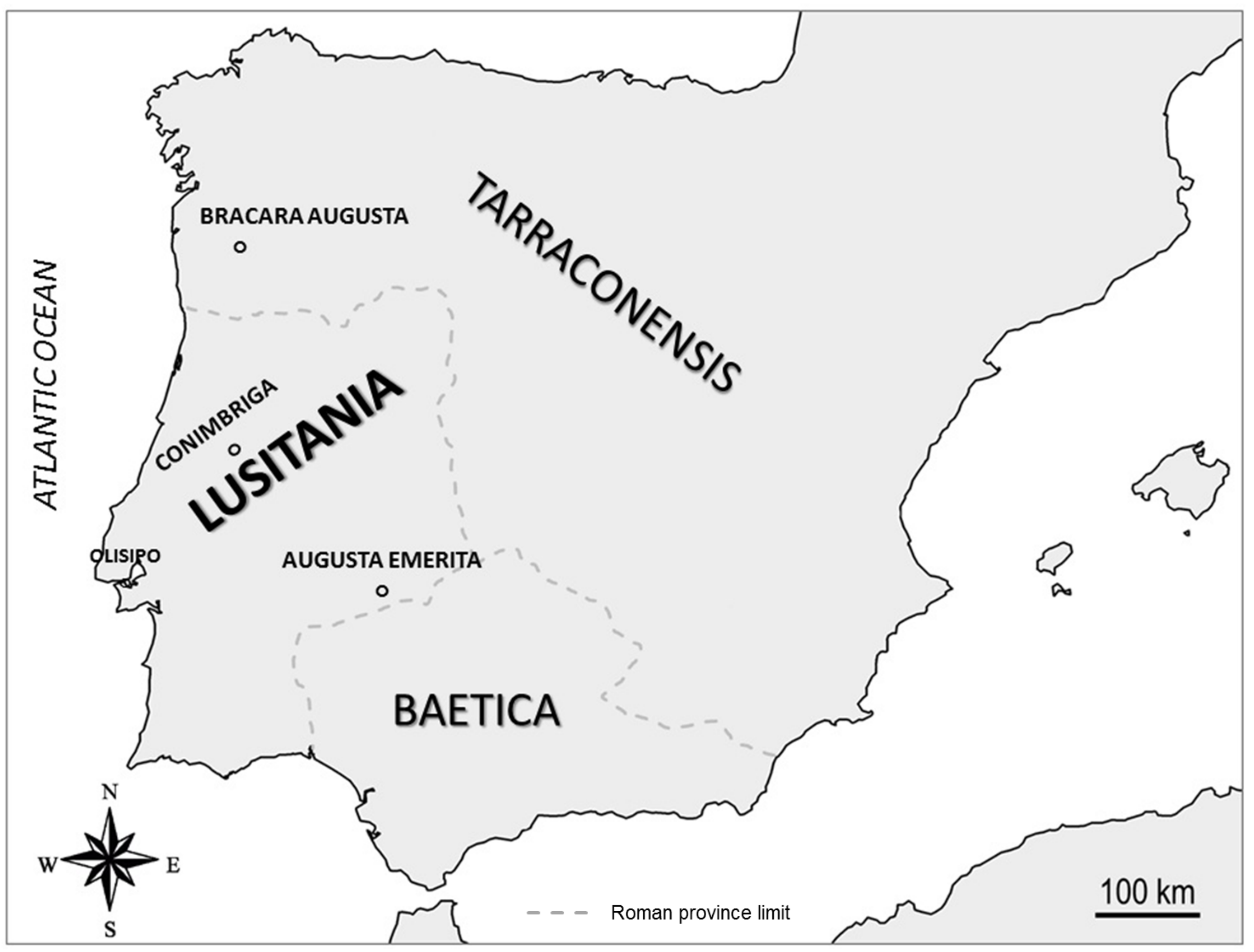




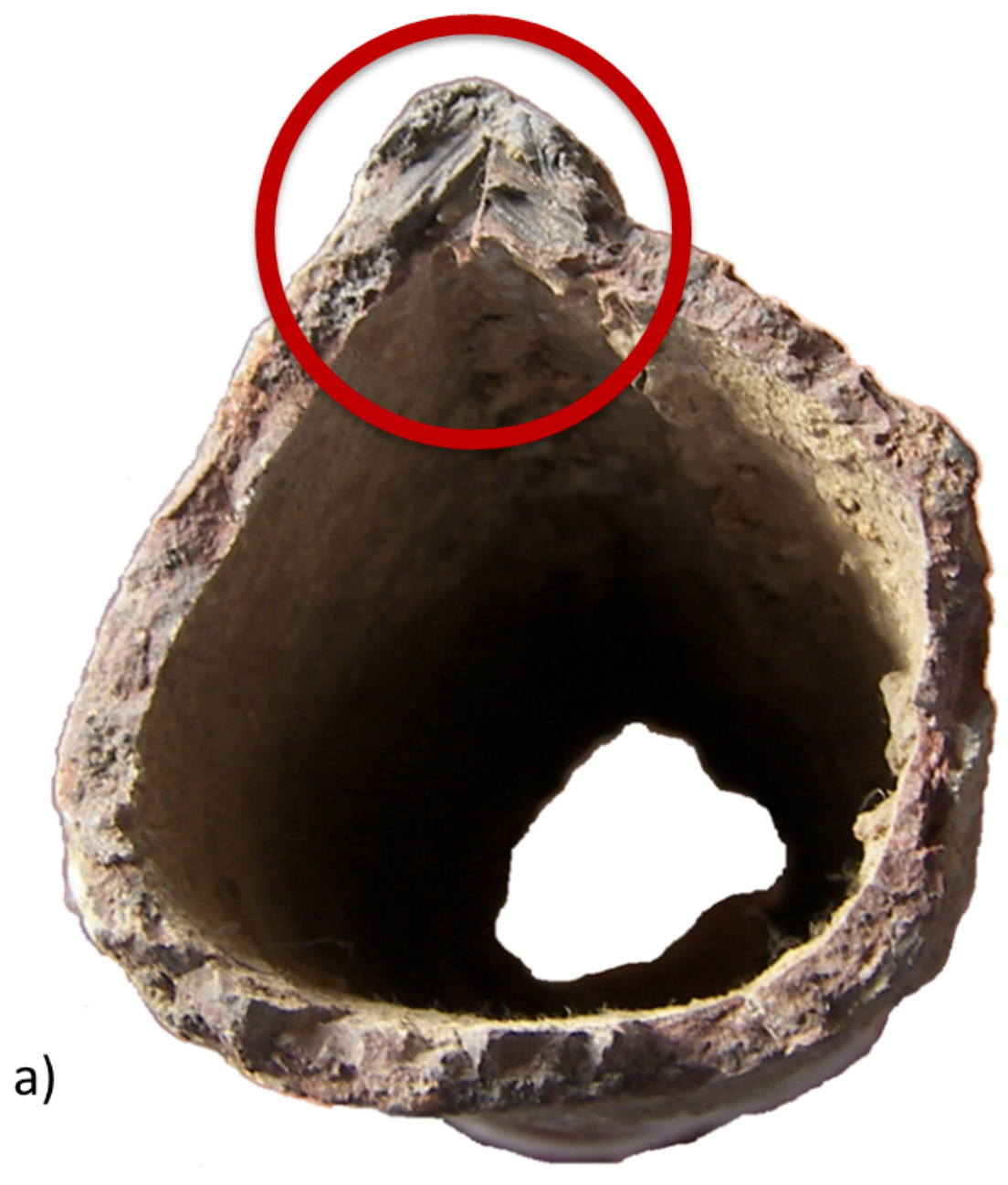

b)

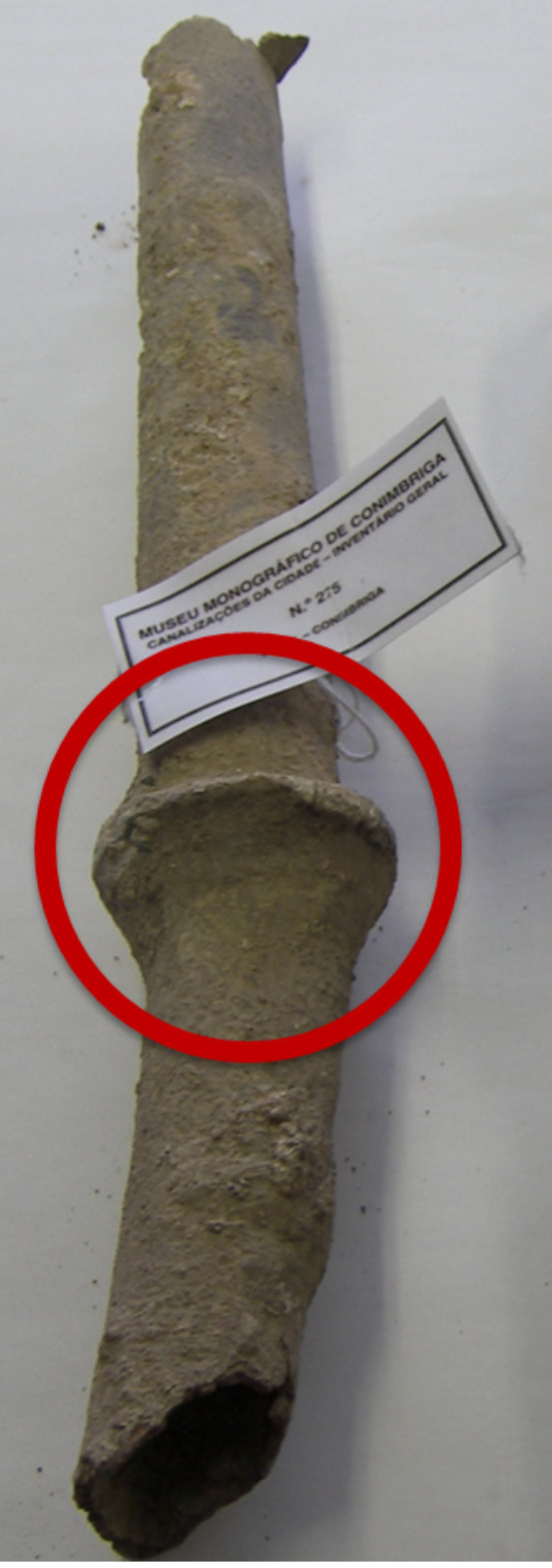



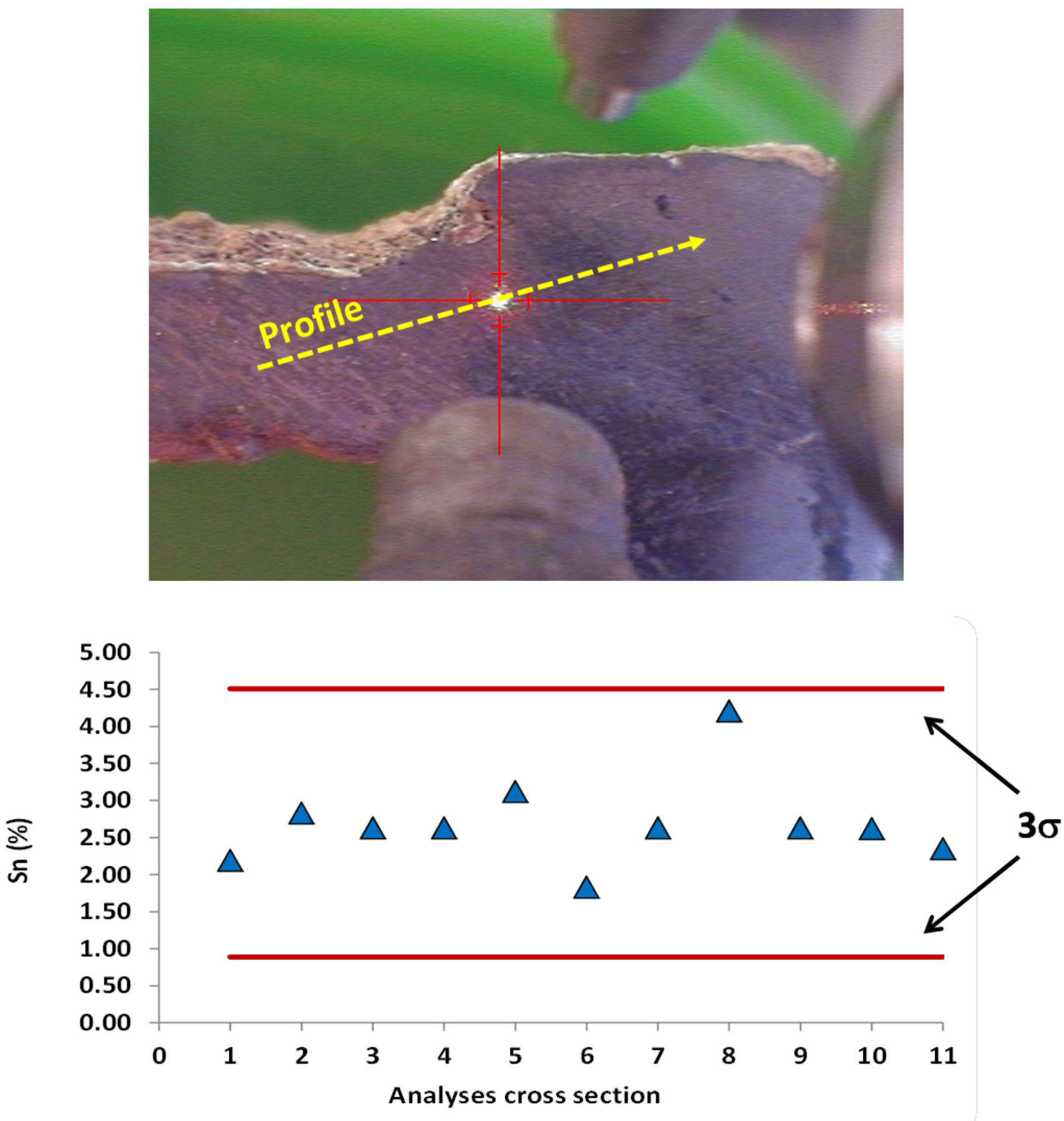


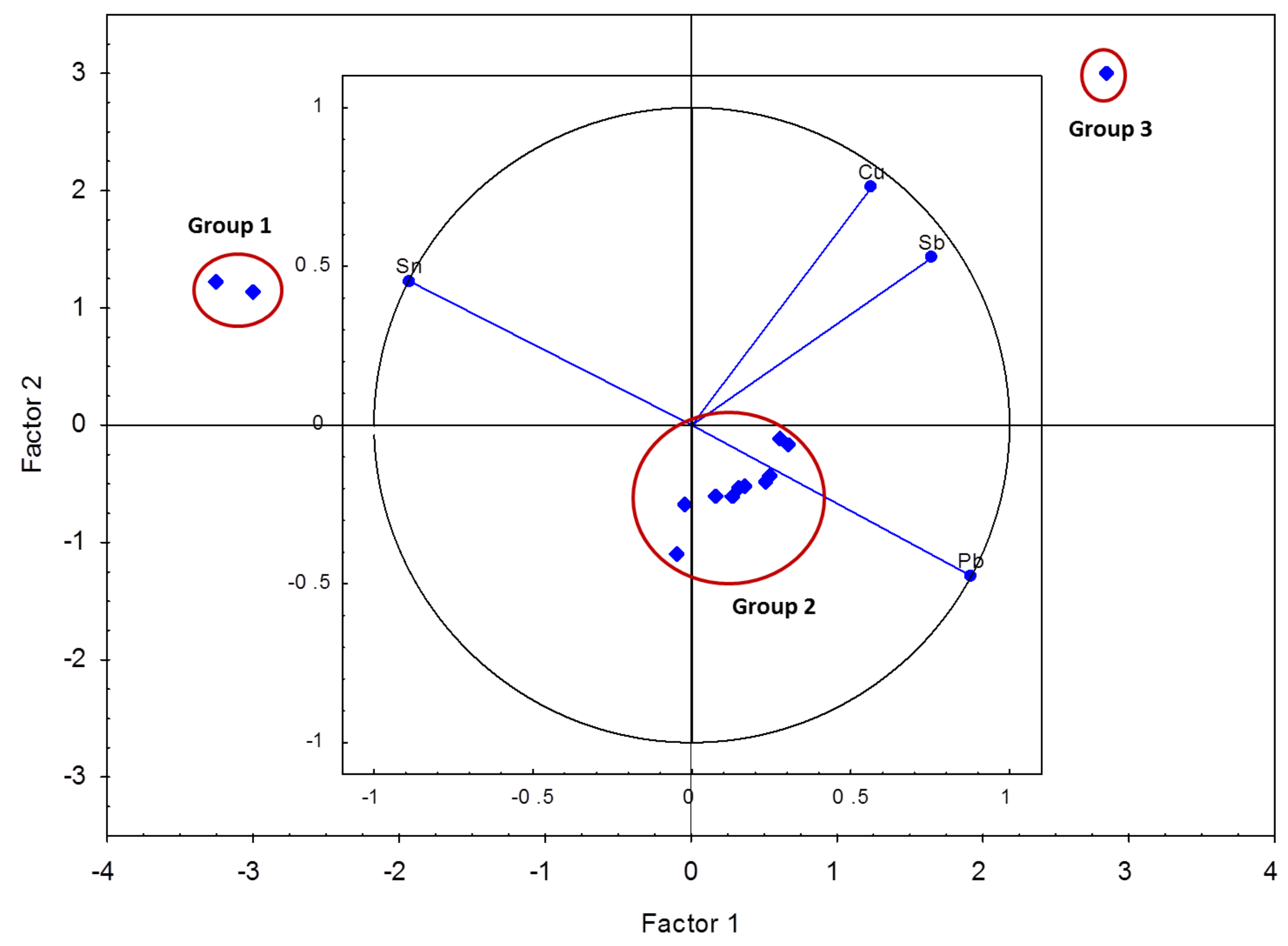




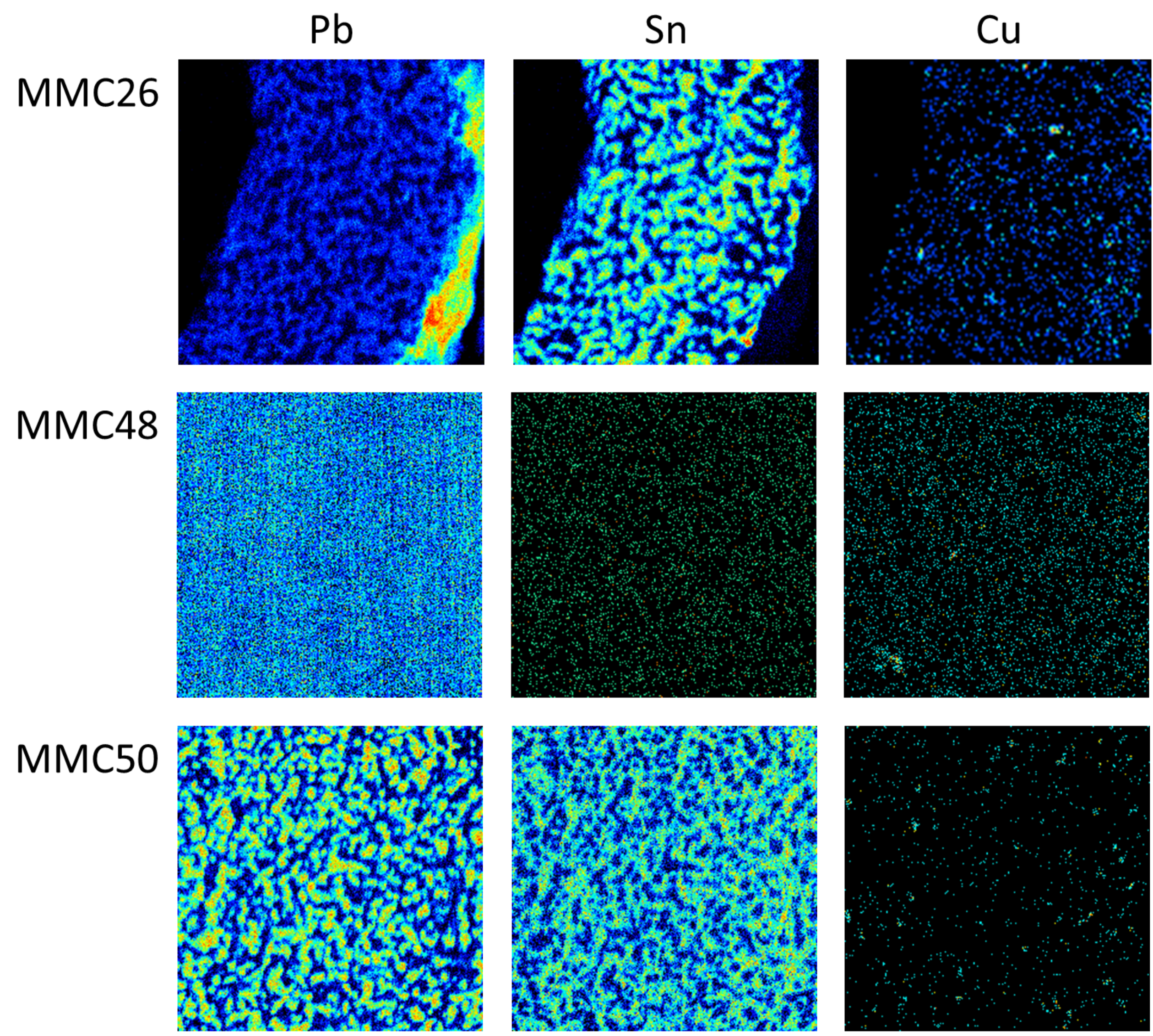



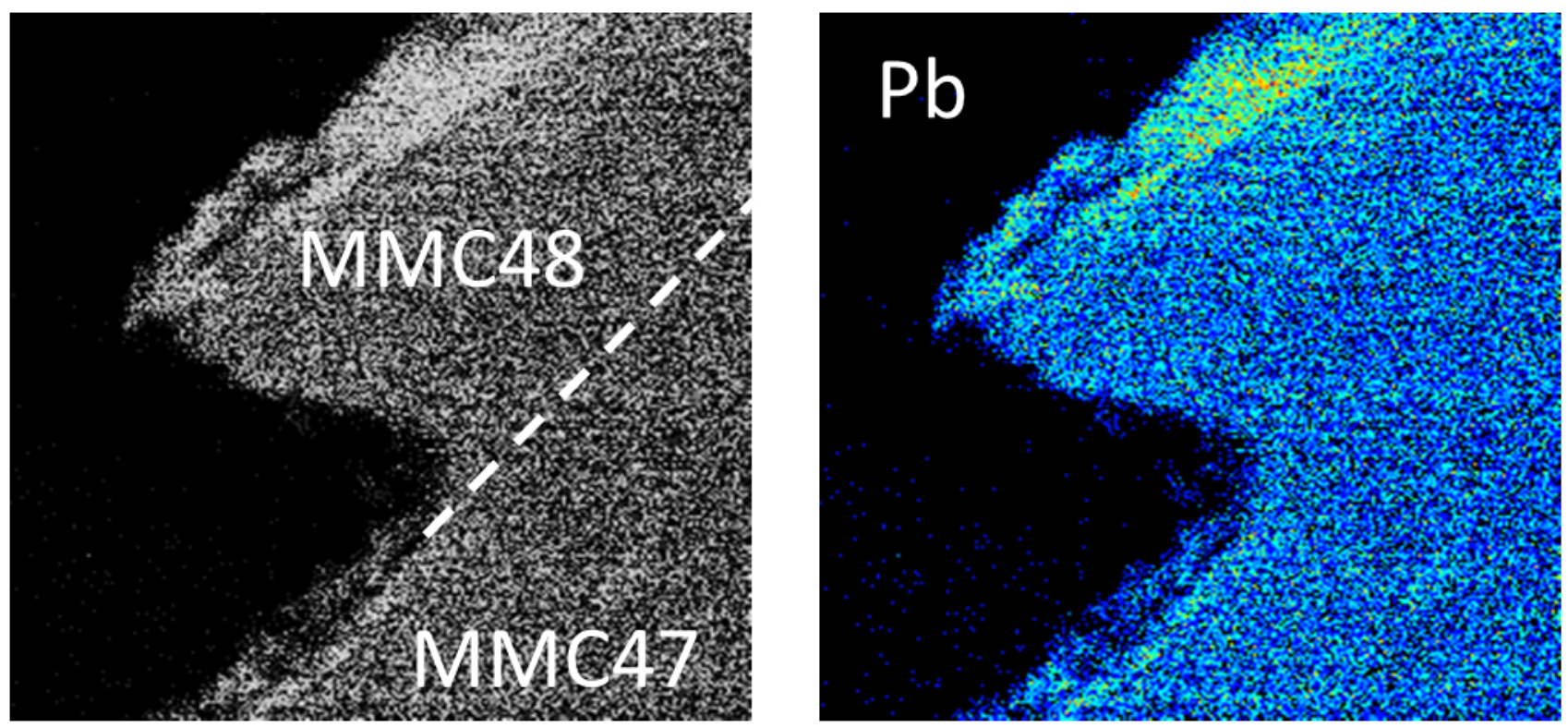


\section{Table 1}

Identification of seams, joints and lead pipes from Conimbriga (MMC - Museu Monográfico e Ruínas de Conímbriga) and Augusta Emerita (M - Consorcio Ciudad Monumental de Mérida, and MM - National Museum of Roman Art, MM).

\begin{tabular}{|c|c|c|}
\hline Reference & Type & Archaeological site \\
\hline MMC11 & Seam & $\begin{array}{l}\text { Conimbriga } \\
\text { (house of water jets) }\end{array}$ \\
\hline MMC26 & Seam & $\begin{array}{l}\text { Conimbriga } \\
\text { (house of water jets) }\end{array}$ \\
\hline ММС36 & Seam & $\begin{array}{l}\text { Conimbriga } \\
\text { (house of water jets) }\end{array}$ \\
\hline MMC41 & Seam & $\begin{array}{l}\text { Conimbriga } \\
\text { (house of water jets) }\end{array}$ \\
\hline MMC42 & Pipe & $\begin{array}{l}\text { Conimbriga } \\
\text { (house of water jets) }\end{array}$ \\
\hline MMC43 & Seam & $\begin{array}{l}\text { Conimbriga } \\
\text { (house of water jets) }\end{array}$ \\
\hline MMC44 & Pipe & $\begin{array}{l}\text { Conimbriga } \\
\text { (house of water jets) }\end{array}$ \\
\hline MMC45 & Seam & $\begin{array}{l}\text { Conimbriga } \\
\text { (house of water jets) }\end{array}$ \\
\hline MMC47 & Pipe & $\begin{array}{l}\text { Conimbriga } \\
\text { (house of water jets) }\end{array}$ \\
\hline MMC48 & Seam & $\begin{array}{l}\text { Conimbriga } \\
\text { (house of water jets) }\end{array}$ \\
\hline MMC50 & Joint & $\begin{array}{l}\text { Conimbriga } \\
\text { (house of water jets) }\end{array}$ \\
\hline MMC51 & Joint & $\begin{array}{l}\text { Conimbriga } \\
\text { (house of water jets) }\end{array}$ \\
\hline M2 & Joint & $\begin{array}{l}\text { Augusta Emerita } \\
\text { (unknown archaeological context) }\end{array}$ \\
\hline MM4 & Joint & $\begin{array}{l}\text { Augusta Emerita } \\
\text { (unknown archaeological context) }\end{array}$ \\
\hline MM11 & Seam & $\begin{array}{l}\text { Augusta Emerita } \\
\text { (unknown archaeological context) }\end{array}$ \\
\hline MM12 & Joint & $\begin{array}{l}\text { Augusta Emerita } \\
\text { (unknown archaeological context) }\end{array}$ \\
\hline
\end{tabular}


Table 2

Micro-EDXRF analyses of standards Au80Ag20 and Au90Ag10 (average \pm standard deviation).

\begin{tabular}{lllll}
\hline & $\begin{array}{l}\text { Au80Ag20 } \\
\text { Au (wt.\%) }\end{array}$ & Ag (wt.\%) & Au90Ag10 & Au (wt.\%) \\
\hline Standard value & 80.2 & 19.8 & 90.15 & Ag (wt.\%) \\
Obtained value & $82.1 \pm 0.4$ & $18.0 \pm 0.4$ & $90.4 \pm 0.1$ & $9.62 \pm 0.06$ \\
Uncertainty & $2.4 \%$ & $9.1 \%$ & $0.3 \%$ & $2.3 \%$ \\
\hline
\end{tabular}


Table 3

Results of micro-EDXRF analysis of the fistulae seals from Conimbriga and Augusta Emerita (n.d. - not detected; * pipes associated to seams).

\begin{tabular}{llllll}
\hline Reference & Type & Pb (wt.\%) & Sn (wt.\%) & Sb (wt.\%) & Cu (wt.\%) \\
\hline MMC11 & Seam & $98.5 \pm 0.1$ & $0.90 \pm 0.22$ & $0.62 \pm 0.05$ & $0.07 \pm 0.01$ \\
MMC26 & Seam & $30.9 \pm 1.2$ & $68.7 \pm 1.2$ & n.d. & $0.06 \pm 0.01$ \\
MMC36 & Seam & $98.2 \pm 0.5$ & $1.06 \pm 0.32$ & $0.70 \pm 0.15$ & $0.07 \pm 0.01$ \\
MMC41 & Seam & $98.5 \pm 0.2$ & $0.47 \pm 0.17$ & $1.03 \pm 0.25$ & $0.05 \pm 0.03$ \\
MMC42* & Pipe & $98.0 \pm 0.3$ & $1.25 \pm 0.09$ & $0.79 \pm 0.23$ & $0.09 \pm 0.01$ \\
MMC43 & Seam & $98.4 \pm 0.3$ & $0.81 \pm 0.20$ & $0.74 \pm 0.14$ & $0.07 \pm 0.03$ \\
MMC44* & Pipe & $98.2 \pm 0.5$ & $0.79 \pm 0.33$ & $0.99 \pm 0.28$ & $0.05 \pm 0.01$ \\
MMC45 & Seam & $98.2 \pm 0.4$ & $0.70 \pm 0.08$ & $1.08 \pm 0.45$ & $0.05 \pm 0.01$ \\
MMC47* & Pipe & $96.8 \pm 0.4$ & $2.80 \pm 0.23$ & n.d. & $0.13 \pm 0.05$ \\
MMC48 & Seam & $97.0 \pm 0.3$ & $2.53 \pm 0.16$ & n.d. & $0.17 \pm 0.02$ \\
MMC50 & Joint & $35.9 \pm 3.8$ & $64.1 \pm 3.9$ & n.d. & $0.07 \pm 0.04$ \\
MMC51 & Joint & $97.3 \pm 0.2$ & n.d. & $2.35 \pm 0.21$ & $0.36 \pm 0.22$ \\
M2 & Joint & $98.0 \pm 0.5$ & $1.04 \pm 0.27$ & $0.84 \pm 0.27$ & $0.11 \pm 0.05$ \\
MM4 & Joint & $97.3 \pm 1.8$ & $1.78 \pm 0.08$ & $1.19 \pm 0.71$ & $0.07 \pm 0.01$ \\
MM11 & Seam & 99.9 & n.d. & n.d. & $0.06 \pm 0.01$ \\
MM12 & Joint & 99.9 & n.d. & n.d. & $0.12 \pm 0.01$ \\
\hline
\end{tabular}




\section{Table 4}

Factor loadings of principal components of $\mathrm{Pb}, \mathrm{Sn}, \mathrm{Sb}, \mathrm{Cu}$ contents on the fistulae seals from Conimbriga and Augusta Emerita (varimax normalized; bold: factor loadings with absolute value higher than 0.7).

\begin{tabular}{lll}
\hline Variable & Factor 1 & Factor 2 \\
\hline $\mathrm{Pb}$ & $\mathbf{0 . 9 8 7}$ & 0.144 \\
$\mathrm{Sn}$ & $\mathbf{- 0 . 9 8 4}$ & 0.167 \\
$\mathrm{Sb}$ & 0.303 & $\mathbf{0 . 8 2 8}$ \\
$\mathrm{Cu}$ & 0.022 & $\mathbf{0 . 9 2 0}$ \\
Explained variance & $\mathbf{6 1 \%}$ & $\mathbf{3 0 \%}$ \\
\hline
\end{tabular}

